\title{
Effectiveness of Sustainable and Systemic Technological Innovations in Enhancing Students Attitude and Improve Learning of Physics in Secondary Schools in Ife, Osun State
}

\author{
Oyetola Oyeniran, Olaniyi Alaba Sofowora \\ Faculty of Education \\ Department of Educational Technology \\ Obafemi Awolowo University, Ile-Ife, Osun State, Nigeria
}

\begin{abstract}
The study investigated the effectiveness of sustainable and systemic innovative learning technologies introduced into secondary school in Osun State. It discussed the concepts of sustainable and systemic innovative technology and how it was used to enhance students' attitude and performance in Physics in secondary schools in Osun State. The study employed the pre-test post-test control group experimental design. Sixty samples were selected purposively from two secondary schools in Ile-Ife based on availability of internet facilities, computer and functional Physics laboratory. The three instruments used were (i) Students Attitude towards Physics (SAP);(ii) Perceived Impact of the ELearning Engrade System on Students Attitude towards Physics (PIESAP) and (iii) Physics Achievement Test (PAT). The results showed that elearning engrade system significantly improved students' attitude and performance in Physics. It was concluded that the innovative strategy enhanced quality of teaching and learning. Students also found the strategy motivating and effective in resolving the challenges of shortage of instructional materials and provision of quality access to education.
\end{abstract}

\section{Introduction}

An appraisal of Physics education in Nigeria reveals some fundamental problems. These problems include inability of the Physics curriculum to meet the technological, daily needs and comfort of the people [5]. Other challenges include poor methods of instruction, lack of qualified teachers, inadequate facilities and teaching equipment Alonge $\{6\}$ also identifies negative attitude of teachers and students as another challenge. These have negative effect on the students which made them to develop phobia for the subjects and hence poor perfom in examinations. A critical examination of the West African Examinations Council (WAEC) and National Examination Council (NECO) reports revealed that there have been consistent reports of students' poor performance in Physics [12].
Apart from the above, there is also the problem of quality of teachers and the negative attitude of the students towards Physics. On teachers' quality, related literature shows that there are insufficient trained teachers to teach Physics in secondary schools in Nigeria. Not only this, many of the teachers lacked technical knowledge of the subject matter and the pedagogy to impact the knowledge $\{14,15,13,7,16$ and 2$\}$. The matter was made worse by lack of relevant teaching facilities and electricity. Teachers often use the conventional method, which researches have proved to be ineffective and inappropriate method of teaching in this age of Information and Communication Technologies (ICTs).

\section{Literature Review}

Scholars like $\{5\},\{2\},\{11\}$ advocate for a change in the methodology of impacting Physics knowledge to students. Jegede and Adedayo[11] advocate for the integration of modern technology. With respect to attitude, literature reviewed show that majority of the students perceive Physics as very difficult subject $\{1,3,17\}$. Similarly, $\{11\}$ identifies ignorance of the relevant and relationship between Physics and their immediate environment as another militating problem affecting the negative attitude of students towards Physics. Another major problem as specified by $\{17\}$ is non integration of innovative technology in teaching and learning of Physics.

According to the National Policy on Education [12] the objectives of studying Physics in schools include among others, provision of basic literary in Physics for functional living in the society and to acquire essential scientific skills and attitudes as a preparation for the technological application of Physics. It is also intended to produce young scientists who would be able to design the technological devices that would make day-to-day activities easier and living more comfortable [5]. It therefore suffices to say that Physics is one of the pivotal subjects in technology. Hence, the need for a better teaching method that will enhance students' attitude and performance in Physics [21]. One of these innovative methods is to create a sustainable 
systemic and innovative learning technology package for teaching and learning Physics. Systemic innovative Technology simply implies the use of modern technologies in a sustainable way to support systemic educational reforms in schools. It is also designed to influence students learning in a sustainable way to greater dimension in a relatively short period of time. One of these innovations is Elearning which is product of Educational Technology.

E-Learning refers to the use of internet technologies to deliver a broad array of solutions that enhance knowledge and performance. E-Learning technologies offer learners control over content, learning sequence, pace of learning, time, and often media by allowing them to tailor their experiences to meet their personal learning objectives. The integration of E-Learning into education involve application of adult learning theories, where educators will no longer serve as the distributors of contents, but will become more involved as facilitators of learning and assessors of competency. Continuing professional development practices in today's fast moving workplace environment increasingly involve the use of modern technologies as part of the quest to provide a flexible and responsive learning experience [17]. According to this school of thought, learning is replaced by interaction opportunities with instructors and other students anywhere, anytime and anyhow. Hence, Elearning offers avenues for students to continue their learning to acquire new and upgrade existing skills at a time and place of their choice. In the wake of shortage of relevant instructional materials and facilities for effective teaching and learning of Physics in secondary schools, there is the need to investigate how e-learning engrade system can be used in a sustainable and innovative way to improve teaching and learning in a scalable way in schools. Hence, the following objectives were drawn.

\section{Research Objectives}

The specific objectives of this research are to:

- develop an E-Learning Engrade System for learning Physics in selected secondary schools in Ife metropolis;

- determine the perceived effectiveness of the ELearning Engrade System as a learning tool in secondary schools; and

- determine the impact of E-learning Engrade system on students attitude towards Physics.

\section{Methodology}

The study employed the pre-test post-test control group experimental design. The target population for this study consisted of all the secondary school students offering Physics in Ile-Ife. The sample used for the study consisted of sixty (60) students that were purposively selected from the population based on those offering Physics as one of their subjects and who were willing to participate in the study. Two schools were selected using stratification based on school ownership (public and private), availability of internet services and ICT facilities in one of the two schools. The schools were purposively assigned to the treatment level. The sixty (60) participants were randomly assigned into two groups containing thirty (30) participants each (experimental and control groups).

\subsection{Research Instruments}

Three instruments and one stimulus material were developed by the researcher. The three instruments were: (i) Students Attitude towards Physics (SAP) questionnaire, (ii) Perceived Impact of the ELearning Engrade System on Students Attitude towards Physics (PIESAP) questionnaire, and (iii) Physics Achievement Test (PAT). The fourth instrument was the stimulus material called "ELearning Engrade System. This is one of the systemic innovative technologies introduced into the schools system in Osun State. It is termed ELearning Engrade System; it is an educational webbased tool which allows teachers to manage their classes online with frequent feedback. It has templates for lesson delivery that could be developed by the teacher. For this study, two topics drawn from the Senior Secondary School 2 Curriculum were developed and uploaded by the researchers, the two topics were; Linear Momentum and Heat Energy. The topics were developed using the Microsoft Power Point before it was uploaded into the Engrade. Students were allowed access to the material by login in with their individual username and password generated for them by the researchers. The package was secured in that, only the students with username and password are the one that were given access to the lessons prepared. It was designed in a way that student can only have access to his/her own account only. There is also a section where students engaged in drill and practices to know how well he/she understands the lessons. The reliability of the instruments was carried out using test-retest method. The instruments were administered on fifteen students selected from a school that was not part of the sample. The reliability values of $0.80,0.83$, and 0.85 were obtained for PAT, SAP, and PIESAP respectively.

\subsection{Treatment Procedure}

The experiment lasted for eight weeks. The first week was used for introduction in both the experimental and control groups. During the first 
Table 1. Perceived Effectiveness of the Innovative E-learning Package

\begin{tabular}{|c|c|c|c|c|c|c|}
\hline $\mathrm{S} / \mathrm{N}$ & Description of items & SA & $\mathrm{A}$ & SD & $\mathrm{D}$ & $\mathrm{U}$ \\
\hline 1 & $\begin{array}{l}\text { The introduction of Technology Enhanced Learning (Opon Imo) is very } \\
\text { innovative }\end{array}$ & $63 \%$ & 23 & 7 & 4 & $6 \%$ \\
\hline 2 & My teacher employs it in teaching & $69 \%$ & $19 \%$ & $9 \%$ & $3 \%$ & 0 \\
\hline 3 & We have been introduced to E-learning Engrade & $57 \%$ & $33 \%$ & $4 \%$ & $3 \%$ & $3 \%$ \\
\hline 4 & My teacher uses E-learning Engrade & $60 \%$ & $20 \%$ & $5 \%$ & $10 \%$ & $5 \%$ \\
\hline 5 & I remember what i learn better using this innovative learning tool & $42 \%$ & $39 \%$ & $15 \%$ & $4 \%$ & 0 \\
\hline 6 & Using E-learning Engrade to teach Physics is interesting & $54 \%$ & $27 \%$ & $12 \%$ & $5 \%$ & $2 \%$ \\
\hline 7 & I understand Physics better using E-learning Engrade & $61 \%$ & $24 \%$ & $9 \%$ & $3 \%$ & $3 \%$ \\
\hline 8 & I prefer learning Physics using E-learning Engrade & $75 \%$ & $15 \%$ & $6 \%$ & $4 \%$ & 0 \\
\hline 9 & E-learning Engrade is motivating than Talk and Chalk & $53 \%$ & $27 \%$ & $15 \%$ & $5 \%$ & 0 \\
\hline 10 & E-learning Engrade is more engaging than Talk and Chalk method & $48 \%$ & $33 \%$ & $10 \%$ & $7 \%$ & $2 \%$ \\
\hline 11 & It is more user friendly than Talk and Chalk & $40 \%$ & $45 \%$ & $12 \%$ & $3 \%$ & 0 \\
\hline 12 & Using E-learning has increased my disposition to Learning Physics & $35 \%$ & $42 \%$ & $8 \%$ & $10 \%$ & $5 \%$ \\
\hline 13 & E-learning is not as effective as Talk and Chalk & $5 \%$ & $7 \%$ & $45 \%$ & $40 \%$ & $3 \%$ \\
\hline
\end{tabular}

Table 2. E-learning Engrade System and Students Attitude

\begin{tabular}{|c|c|c|c|c|c|c|}
\hline $\mathbf{S} / \mathbf{N}$ & & $\mathbf{S A}$ & $\mathbf{A}$ & SD & $\mathbf{D}$ & $\mathrm{U \%}$ \\
\hline 01. & Physics is now made simpler & 62.5 & 25 & 9.4 & 3.1 & 0 \\
\hline 02. & I now see Physics as my best Science subject & 69 & 22 & 6.9 & 1.5 & 0.8 \\
\hline 03. & I prefer Physics to other subjects. & 56 & 24 & 10. & 0 & 2 \\
\hline 04. & Physics lessons are now captivating & 69 & 29 & 0 & 0.7 & 0 \\
\hline 05. & I love Physics as a profession & 66 & 21 & 8 & 3 & 2 \\
\hline 06. & I wish the periods for Physics are increased & 64 & 28 & 5 & 3 & 0 \\
\hline 07. & I love studying Physics independently & 59 & 32 & 7 & 2 & 0 \\
\hline 08. & I now read Physics every day. & 53 & 36 & 5 & 6 & 0 \\
\hline 09. & Physics lessons are interesting & 61 & 30 & 9 & 0 & 0 \\
\hline 10. & Physics is now made relevant to other subjects. & 79 & 17 & 2 & 1 & 1 \\
\hline 11. & My attitude has improved significantly & 71 & 24 & 2 & 3.0 & 1 \\
\hline 12. & I read my Physics note everyday & 55 & 30 & 10 & 3 & 3 \\
\hline 13. & Calculations in Physics are made easier. & 92 & 6 & 0 & 2.8 & 0 \\
\hline 14. & Studying Physics is no longer boring & 80 & 15 & 2 & 3 & 0 \\
\hline 15. & I wish to study Physics in the higher institution. & 69 & 20 & 5 & 5 & 1 \\
\hline
\end{tabular}

( $\mathrm{SA}=$ Strongly Agree, $\mathrm{A}=$ Agree, $\mathrm{SD}=$ Strongly Disagree, $\mathrm{D}=$ Disagree, $\mathrm{U}=$ Undecided)

Table 3. Students Performance in Physics

\begin{tabular}{|c|c|c|c|c|c|c|}
\hline Test & Group & $\mathrm{N}$ & $\frac{\text { Mean }}{\mathrm{X}}$ & S.D & $\mathrm{t}$-value & $\mathrm{p}$ \\
\hline \multirow[b]{2}{*}{ Pre-test } & \multirow{2}{*}{$\begin{array}{l}\text { Experimental } \\
\text { Control }\end{array}$} & 30 & 18.47 & 2.56 & \multirow[b]{2}{*}{1.303} & \multirow[b]{2}{*}{0.198} \\
\hline & & 30 & 17.60 & 2.60 & & \\
\hline Post-test & $\begin{array}{l}\text { Experimental } \\
\text { Control }\end{array}$ & $\begin{array}{l}30 \\
30\end{array}$ & 46.40 & 3.08 & $\begin{array}{l}* \\
17.516\end{array}$ & 0.05 \\
\hline
\end{tabular}

week, members in the experimental group were given an access code in terms of username and password in order to have access to the stimulus material by logging in to the address which is www.engrade.com. The second week was used for administering the pre-attitude questionnaire on the experimental group and conducting pre-test in both the experimental and control groups, and guiding the experimental group on how to use the stimulus material. The third to fourth week was used for teaching. The experimental group used the ELearning Engrade System independently for learning while the control group was taught using the conventional method. The post-test was conducted during the sixth week in both groups while the retention test was conducted two weeks after the post test.

\section{Results}

Find below the results of the data analysed in respect of the objectives.

The results showed that students perceived the innovative learning tool as effective in teaching Physics in the selected secondary schools. Eighty five percent of the students perceived E-learning as 
being more effective in teaching Physics than the traditional chalk and talk method. Similarly, $86 \%$ of the sample perceived the introduction of systemic innovative and sustainable technology as very innovative. Eighty five percent of the sample opined that it is user friendly than talk and chalk method so also $81 \%$ were of the opinion that it is more engaging than traditional talk and chalk method.

On the effectiveness of the package on the attitude of the students towards Physics, the results showed that $80 \%$ of the sample was of the view that Physics lessons were easier through the use of the package. Students $(88 \%)$ rated Physics as one of the best Science subjects, not only this it was agreed that their attitude increased significantly (93.8\%). In addition, $94.9 \%$ of the sample opined that studying Physics is no longer boring as it used to be. Also significant number of the sample (96.4\%) said Physics is now made relevant to other subjects and their day living. As a result of the use of the systemic and sustainable innovative technology in teaching Physics students who formerly were not willing to study Physics have now develop interest and are willing to take it as a profession(88.6\%). The above results corroborated the findings of [10], [8], [9] and [21].With respect to the ability of the innovative strategy in enhancing students performance, the results showed that the package effectively enhanced students performance in Physics $(t=17.52 \mathrm{p}<0.05)$.

\section{Conclusions}

It was concluded that the innovative strategy that was introduced enhanced the quality of teaching and learning of Physics in secondary schools. It was also very effective in improving students' attitude to learning Physics. Students found the strategy motivating and effective in resolving the challenges of shortage of instructional materials and provision of quality access to education especially in this period of economy recession.

\section{Recommendations}

The following recommendations were made:

- E-Learning Engrade System should be integrated into education curriculum in Nigeria.

- Federal Government should as a matter of urgency implement the National Policy on Technology as it relates to education;

- Qualified Physics teachers who are skilled in the use of modern technologies be employed to teach in the secondary schools;

- Schools should be equipped with necessary infrastructure, relevant instructional materials and electricity;
- Nigeria should implement the UNESCO directive of the budgetary allocation to education;

- Government should encourage more private and industrial participation in financing education. This can be achieved by allowing the Telecommunication Industries to provide broadband facilities at a subsidized rate to schools for teaching and learning.

\section{References}

[1] Adedayo, J .O., (2008). Effects of electronics artisan's background and competence in science and technology advancement in Nigeria. Research in Curriculum Studies. 5(1). 132-136.

[2] Adedayo, J. O., (2010). Effect of teacher's qualification on the performance of senior secondary school students in Physics: Implication on technology. A paper presented at the 6th annual conference of the Nigerian Educational Research Association University of Nigeria, Nsukka; $5^{\text {th }}$ 7th November

[3]Adedire, O. D., (2016). Effects of Adaptive Hypermedia earning Package on knowledge Acquisition and Retention of Physics Concepts among senior Secondary School Students in Ile-Ife. A Master of Education Thesis submitted to the Department of Educational Technology And Library studies, Obafemi Awolowo University, IleIfe.

[4] Ajayi, P. O., (2007). Evaluation of the implementation of senior secondary school Physics curriculum in south west Nigeria. An unpublished Ph.D. thesis, University of Ado-Ekiti, Nigeria.

[5] Ajayi, P. O., (2008). Evaluation of instructional materials for the implementation of senior secondary school Physics curriculum in Nigeria. Nigerian Journal of Counseling and Applied Psychology. 4(1). 100-110.

[6]Alonge, E. I., (1982). The relevance of traditional Mathematics for relevant science education in Africa. Journal of Science Teacher Association of Nigeria (STAN). 21(1). 24-44.

[7] Fajewonyomi, A. A., (2007). Reviving higher education relevance in Nigeria. A paper presented at the 3rd Faculty week and annual national conference; Faculty of Education, University of Maidugurim, Nigeria. $26^{\text {th }}$ 27th September.

[8] Fajola, O.O. (2000). Effect of three modes of computer based instuctional stratgies on student learningoutcomes in biology. Unpublished Ph.D thesis, University of Ibadan, Nigeria.

[9] Gambari, A.I., (2010). Effect of computer supported cooperative Learning strategies on the performance of senior secondary student in Physics, in Minna, Nigeria. Unpublished PhD Thesis, University of Ilorin, Nigeria.

[10] Halluck, O., (2008). The influence of computer assisted instruction on students conceptual understanding 
of chemical bonding and attitude towards Chemistry. Journal of Science Direct, 51, (1), 423-438

[11] Jegede, S.A. and Adedayo, J.O., (2013). Enriching Physics education in Nigeria; towards Enhancing a Sustainable technological development. Greener Journal of Educational Research, 3, (2), 80-84. Retrieved from www.gjournals.org on July 13, 2016.

[12] National Examination Council (NECO,0 2011). Cheif Examiners' report. Research and statics Unit NECO Head quaters, Minna, Niger state, Nigeria.

[13] Nwagbo, C., (1995). Effect of guided inquiry and expository teaching methods on the achievement in an attitude to Biology of students of different scientific literacy. Online at http://www.pepreal.cl/FIE/pdf/lopbc/ nwagbo.pdf

[14] Oghazi, J. N., (1987). Using co-operative education students' performances. Vocational Education Journal. 1(1).162-169.

[15] Olarewaju, A. O., (1986). Census of students' underachievement. 27th Annual Conference Proceedings of the STAN. 80-87.

[16] Omotayo, K. A., (2009). An investigation into the acquisition of scientific attitude among junior secondary school students. Journal of National Association of Women in Academic. 1(1). 82-89.

[17] Oyeniran, O. and Sofowora, O.A. (2016). Ensuring quality teaching and learning of Physics In senior secondary schools In Osun State ,Nigeria .CICE 2016 Conference Proceedings

[18]Sofowora, O., (2011). Information Technology and Educational Branding as innovative technology for development, management and quality education in a Nigerian university. Journal of Librarianship and Law, Kampala International University, Dar Es-Salam, Tanzania. 1. 45-60

[19] Sofowora, O. A., (2014) Information and Communication Technologies as a meaningful and sustainable tool for enhancing transnational collaboration in education. Meditrranean Journal of Social Science Rome-Italy.5 (23), 1465-1469.

[20] Sofowora, O. A. and Akingbile, T., (2016). Provision of sustainable and quality higher education to the disenfranchised youths in Southwestern Nigeria using distance learning mode. INCEDI conferenceProceedings Methodist University College, Accra Ghana

[21]Soyibo, S. K., (1986). A critical review of some of the causes of students' poor performance in science. Journal of Science Teacher's Association of Nigeria (STAN). 27th annual conference. 80-87. Unified Tertiary Institutions Matriculations Board (2012). Guidelines for Admissions. Lagos. 